\title{
Single-tube, non-interrupted reverse transcription PCR for detection of infectious pancreatic necrosis virus
}

\author{
Way-Shyan Wang*, Yea-Ling Wi, Jainn-Shyan Lee \\ Department of Veterinary Medicine, National Chung Hsing University, Taichung, Taiwan 402, ROC
}

\begin{abstract}
An assay using a single-tube, non-interrupted reverse transcription-polymerase chain reaction (RT-PCR) was established for the detection of infectious pancreatic necrosis virus (IPNV). Two primer sets, Pr D and Pr F, which framed a region within the gene coding for IPNV VP2 protein were used to amplify specific fragments of the IPNV genome. Amplified products were detected in cultured chinook salmon embryo cells (CHSE-214) infected with different IPNV strain isolates including $\mathrm{WB}, \mathrm{Ja}, \mathrm{Sp}, \mathrm{Ab}, \mathrm{VR} 299,3372, \mathrm{MFK}$, and CV-HB-1, but not in uninfected CHSE-214 nor in cells infected with IHNV or infectious bursal disease virus (IBDV). The detection limit of this method was estimated with purified viral RNA from the WB strain of IPNV to be between $15 \mathrm{fg}$ and $15 \mathrm{pg}$ in ethidium bromide-stained gels
\end{abstract}

KEY WORDS: RT-PCR - IPNV · Fish · Virus

Infectious pancreatic necrosis virus (IPNV) is an economically important fish pathogen which causes severe acute infections in young salmonids resulting in high mortality (Elazhary et al. 1976, Hedrick et al. 1983, Wolf 1988, Christie et al. 1990, Sneller et al. 1992, Novoa et al. 1995). The virus, which belongs to the family Birnaviridae (Dobos et al. 1979, Persson \& MacDonald 1982, Brown 1986, Wolf 1988), is mediumsized, non-enveloped, and contains 2 segments of dsRNA (Dobos 1976). Genome segment A encodes a polypeptide that includes the major capsid protein, VP2, and the minor capsid protein, VP3, which is cleaved by the protease (MacDonald \& Dobos 1981, Nagy et al. 1987). Meanwhile, genome segment $B$ encodes a single protein, namely the virion-associated transcriptase (VP1) (Mertens et al. 1982, Nagy et al. 1987. Manning \& Leong 1990, Dopazo et al. 1994, Dobos 1996).

At present, since viral diseases in fish cannot be easily cured by therapeutic reagents, rapid and effec-

\footnotetext{
•E-mail: wswang@dragon.nchu.edu.tw
}

tive diagnosis of aquatic birnavirus is essential for the control of viral diseases. Despite the fact that serological diagnostic methods such ELISA (Shankar \& Yamamoto 1994), immunodot blot (Hsu et al. 1989), fluorescent antibody test, coagglutination test (Kimura et al. 1984), and CDNA probes (Dopazo et al. 1994) have been developed for IPNV detection, these methods have still been deemed not sufficiently sensitive, rapid, or economically feasible for use under field conditions (Lee et al. 1994, Lopez-Lastra et al. 1994, Wang et al. 1995). Recently, a rapid and sensitive 2-step reverse transcription-polymerase chain reaction (RT-PCR) assay for identifying IPNV in infected cell cultures and fish tissue samples has been described (Rodak et al. 1988, Lopez-Lastra et al. 1994, Blake et al. 1995, Lee et al. 1995, Wang et al. 1995). This method was further modified so that all reagents required for both RT and PCR were added into a single tube and run through a non-interrupted thermal cycling program as described for the detection of rotavirus (Xu et al. 1990) and infectious bursal disease virus (IBDV) (Lee et al. 1994). For routine diagnostic laboratories, the single-tube RTPCR method is easier and more rapid than the 2-step RT-PCR method. We describe in this paper a non-interrupted RT-PCR in a single tube for the detection of IPNV.

Materials and methods. Viruses and cells. Virus isolation was essentially a modification of the method described by Wang et al. (1995). Eight IPNV strain isolates including WB, Ja, Sp, Ab, VR299, 3372 (isolated from eel in Taiwan), MFK (isolated from milk fish in Taiwan), and CV-HB-1 (isolated from hard clam in Taiwan) were used. These IPNV isolates were propagated in CHSE-214 (chinook salmon embryo cell) with Eagle's minimum essential medium (MEM, Sigma Chemical Co., St. Louis, MO, USA) containing 10\% fetal bovine serum (FBS) (Gibco BRL Life Technologies Inc., NY, USA) at $18^{\circ} \mathrm{C}$ for 5 to $6 \mathrm{~d}$. The titer, 
$\mathrm{TCID}_{50} \mathrm{ml}^{-1}$, of the virus was determined. The crossreactivity of the oligonucleotide primers in this study was tested using infectious haematopoietic necrosis virus (IHNV), another important fish pathogenic virus which has been isolated from cultured ayu in Taiwan, and IBDV (Lee et al. 1994), which is a pathogenic virus of chickens within the family Birnaviridae. All stains of IPNV, IHNV, and IBDV were confirmed by immunoblot assay to be the right viruses.

Oligonucleotide primers. Primers were chosen according to the cDNA sequence of strains Ja and N1 of the IPNV as reported by Duncan \& Dobos (1986) and Havarstein et al. (1990). Two specific IPNV primer sets, namely Pr D and Pr F (Table 1), were synthesized with reference to the published primers (Lee et al. 1994, Wang et al. 1995).

Single tube $\boldsymbol{R T}$-PCR. The RT-PCR reaction was designed so that all components for reverse transcription and polymerase chain reaction (Gelfand \& White 1990, Kawasaki 1990) could be run in a simple noninterrupted thermal program. Each reaction tube containing target viral RNA, $0.5 \mu \mathrm{M}$ of each primer set $(\mathrm{Pr}$ D or Pr F), and $50 \mu$ l of wax (DnaWax, Finnzymes Oy, Espoo, Finland) was heated up to $110^{\circ} \mathrm{C}$ for $10 \mathrm{~min}$ to denature the target RNA and then cooled on ice for 2 min. Then each tube was added in the following order: $100 \mu \mathrm{M}$ of each of the 4 deoxynucleoside triphophates (dNTP, HT Biotechnology Ltd., Cambridge, UK), $1 \times \mathrm{RT}$ reaction buffer $\left(10 \mathrm{mM}\right.$ Tris- $\mathrm{HCl}_{\text {, }}$ $50 \mathrm{mM} \mathrm{KCl}, 1.5 \mathrm{mM} \mathrm{MgCl}_{2}$ ), and $20 \mathrm{U}$ of reverse transcriptase (SuperScript II, BRL, Gaithersburg, MD, USA). After the wax firmed, to each tube was added in the following order: $3 \mathrm{U}$ of Taq DNA polymerase (BRL, Gaithersburg, MD, USA), $1 \times \mathrm{PCR}$ reaction buffer, and $50 \mu l$ mineral oil (Sigma Chemical Co., St. Louis, MO, USA) to make up a total volume of $150 \mu \mathrm{l}$. Each tube was incubated in a thermal cycler $(\mathrm{PC} 700$; Astec Co., Japan) set to the following program: $50 \mathrm{~min}$ at $42^{\circ} \mathrm{C}$ (for RT reaction), then $5 \mathrm{~min}$ at $95^{\circ} \mathrm{C}$ (for inactivation of reverse transcriptase and denaturation of DNA); 35 cycles of $94^{\circ} \mathrm{C}$ at $1 \mathrm{~min}, 55^{\circ} \mathrm{C}$ at $1 \mathrm{~min}$, and $72^{\circ} \mathrm{C}$ at $1 \mathrm{~min} 30 \mathrm{~s}$; and then a final incubation for $7 \mathrm{~min}$ at $72^{\circ} \mathrm{C}$. The amplified product was analyzed for size following electrophoresis $(80 \mathrm{~V}, 1.5 \mathrm{~h})$ in $1.5 \%$ agarose gels and staining with ethidium bromide.

Table 1. Specific primer sets for infectious pancreatic necrosis virus

\begin{tabular}{|c|c|c|c|}
\hline Primer set & $\begin{array}{l}\text { VP2 } \\
\text { location }\end{array}$ & Sequence & $\begin{array}{l}\text { Product } \\
\text { length (bp) }\end{array}$ \\
\hline Pr D & $419-693$ & $\begin{array}{l}\text { 5'-CGGAAATACGACATCCAGAGC-3' } \\
\text { 5'-TGGCTCCGTTCATGGACTGG-3' }\end{array}$ & 274 \\
\hline PrF & $807-1330$ & $\begin{array}{l}\text { 5'-GCCGACATCGTCAACTCCAC-3' } \\
5^{\prime} \text {-GACAGGATCATCTTGGCATA-3' }\end{array}$ & 524 \\
\hline
\end{tabular}

Viral RNA purification. Viral RNA was purified according to the method of Lee et al. (1994). The WB strain of IPNV was propagated in CHSE-214 and concentrated with polyethylene glycol 10000 (PEG, Sigma Chemical Co., St. Louis, MO, USA). After centrifuging $(10000 \times g, 1 \mathrm{~h})$, the pellet was resuspended in TNE buffer $(0.01 \mathrm{M}$ Tris- $\mathrm{HCl}, p H 7.6 ; 0.1 \mathrm{M} \mathrm{NaCl}$; and $0.001 \mathrm{M}$ EDTA), followed by extraction with Freon TF (DuPont, Sydney, Australia), and the aqueous phase was centrifuged isopycnically in a stepwise gradient of $40 \%, 30 \%$, and $20 \% \mathrm{CsCl}_{2}$ (Sigma Chemical Co., St. Louis, MO, USA).The viruses banding at a buoyant density of $1.33 \mathrm{~g} \mathrm{ml}^{-1}$ in $\mathrm{CsCl}_{2}$ gradient were collected and pelleted by centrifugation at $132000 \times g$ at $4^{\circ} \mathrm{C}$ for $2 \mathrm{~h}$. The pellets were resuspended in TNE buffer containing $0.5 \%$ sodium dodecyl sulfate, and proteinase $\mathrm{K}$ was added to a final concentration of $1 \mathrm{mg} \mathrm{ml}^{-1}$. After incubation at $37^{\circ} \mathrm{C}$ for $2 \mathrm{~h}$, the viral RNA was extracted with phenol and chloroform (Wang et al. 1995). Viral dsRNA was purified with LiCl (Sigma Chemical Co., St. Louis, MO, USA) precipitation (Diaz-Ruiz et al. 1978) and then washed twice with $70 \%$ ethanol to remove the $\mathrm{LiCl}$. Finally, the purified viral dsRNA was resuspended in TE buffer $(0.01 \mathrm{M}$ Tris- $\mathrm{HCl}, \mathrm{pH} 8.0$; $0.001 \mathrm{M}$ EDTA).

Detection limit assay. Two primer sets, Pr D and Pr F, were used for this assay. The purified IPNV-WB strain RNA template was serially diluted in 10-fold increments with $0.5 \%$ DEPC-water (Sigma Chemical Co., St. Louis, MO, USA) from $15 \mathrm{ng}$ to $0.015 \mathrm{fg}$.

Viral RNA detection in fish organs. IPNV free cultured rainbow trout (about 5 to $6 \mathrm{~cm}$ ) were infected with the WB stain of IPNV (106 TCID $50 \mathrm{ml}^{-1}$ ) by bath immersion for $30 \mathrm{~min}$. Negative control fish were immersed in MEM-containing water. Four days after post-infection, the infected rainbow trout organs including kidney, gill, intestine, liver, and spleen were collected and homogenized. Then $100 \mu \mathrm{l}$ of the organ mixture was reacted with $900 \mu$ lysis buffer $(8 \mathrm{M}$ guanidium $\mathrm{HCl}, 0.1 \mathrm{M}$ EDTA, $0.3 \mathrm{M}$ sodium acetate) and cooled in an ice bath for $20 \mathrm{~min}$. Next, $1 \mathrm{ml}$ of a phenol/ chloroform/isoamyl alcohol (25:14:1) mixture was added to the reaction tube, and the combined contents were shaken and centrifuged at $12000 \times g$ for $10 \mathrm{~min}$. The aqueous phase was collected and the same amount of chloroform/isoamyl alcohol (24:1) was added; the solution was again mixed well. After centrifugation, the resulting aqueous phase was collected, and the 2 combined aqueous phases precipitated with $100 \%$ ethanol. The pelleted RNA was then resuspended in DEPC water for the single tube RTPCR reaction. 


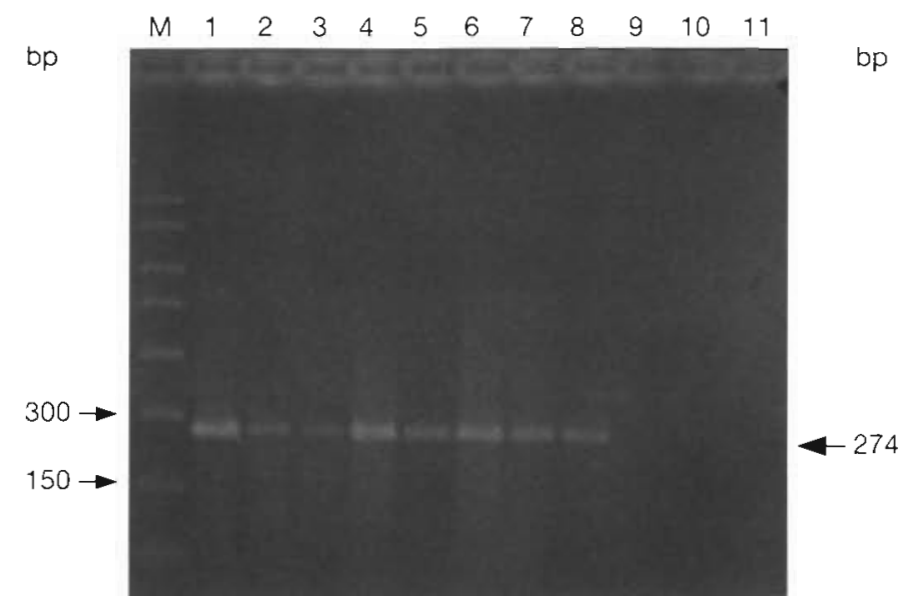

Fig. 1. Specificity of single tube RT-PCR assay using the primer D set. Lane M: molecular weight standard; Lane 1: WB; Lane 2: Ja; Lane 3: Sp; Lane 4: Ab; Lane 5: VR299; Lane 6: 3372; Lane 7: MFK strain; Lane 8: CV-HB-1; Lane 9: IHNV; Lane 10: IBDV; Lane 11. uninfected CHSE-214 cell lysate

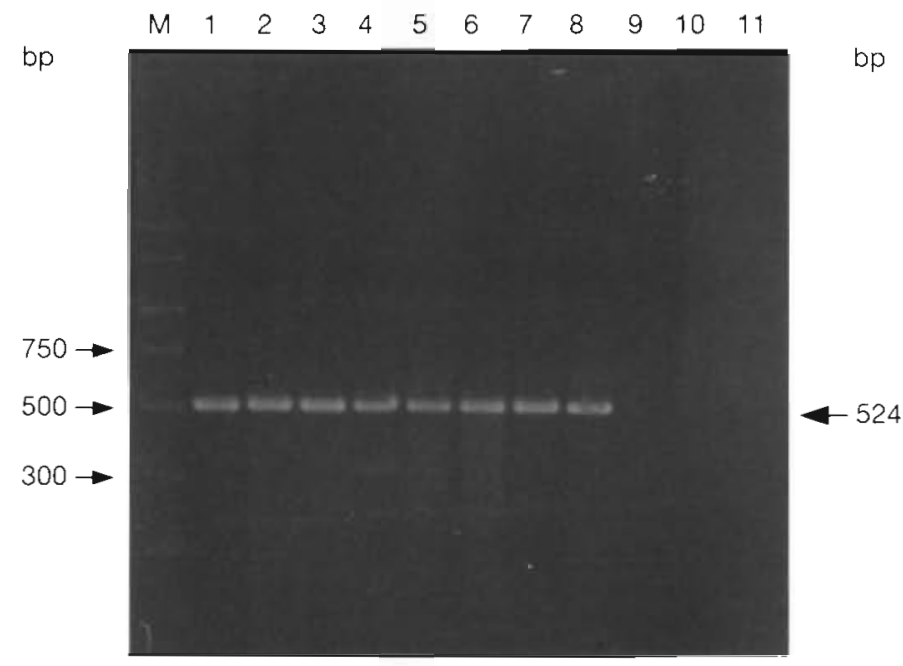

Fig. 2. Specificity of single tube RT-PCR assay using the primer $F$ set. Lane $\mathrm{M}$ : molecular weight standard; Lane 1: WB Lane 2: Ja; Lane 3: Sp; Lane 4: Ab; Lane 5: VR299; Lane 6: 3372; Lane 7: MFK strain; Lane 8: CV-HB-1; Lane 9: IHNV; Lane10: IBDV; Lane 11: uninfected CHSE-214 cell lysate

Results. Specificity of the single tube RT-PCR method. An amplified product of 274 bp by the single tube RT-PCR method using the Pr D primer could be detected with the nucleic acids from 8 IPNV isolates (Fig. 1). However, no fragment could be seen when the same primer set was reacted with either the nucleic acids extracted from IHNV (lane 9), IBDV (lane 10) or uninfected CHSE-214 (lane 11). Under similar conditions, an amplified product of $524 \mathrm{bp}$ from the IPNV was observed in the agarose gel when Pr F primer was used (Fig. 2).
Detection limit of the single tube RT-PCR method. Viral RNA, in a series of dilutions in 10 increments ranging from $1.5 \mathrm{ng}$ to $0.15 \mathrm{fg}$, was tested by RT-PCR for detection by the standard single-tube RT-PCR method described here. The detection limit using the Pr D primer was $15 \mathrm{fg}$, which correlates to about 200 virus particles (Fig. 3). When the Pr F primer was used, the detection limit was $15 \mathrm{pg}$, or about 20000 viral particles (Fig 4).

Viral RNA detection in fish organs. Viral RNA. in fish tissues could be detected by the single tube RT-PCR method without any interference from the RNA of fish cells (Figs. 5 \& 6).

Discussion. PCR amplification has become a standard method in molecular biology research, and is used in diagnostic laboratories because of its high sensitivity and specificity. RT-PCR has been developed for detecting IPNV RNA but the protocols always require 2 separate major stages: RT and a PCR cycle. Previous studies have shown that the Pr D and Pr F primers are very specific for IPNV (Lee et al. 1995, Wang et al, 1995). The single tube, non-interrupted RT-PCR method described here is easier and faster than the 2-step RT-PCR procedures described in the earlier reports, particularly with a large number of samples. We have shown that viral IPNV RNA can be successfully detected by using the simplified RTPCR protocol in which the 2 stages are combined and run sequentially in a single tube. Furthermore, the primer sets identified in the study did not react with nucleic acid from IBDV, IHNV, or uninfected cells.

The detection limits of the assay were $15 \mathrm{fg}$ and $15 \mathrm{pg}$ for primer $\mathrm{Pr} \mathrm{D}$ and $\mathrm{Pr} F$, respectively. This detection limit is same as that of the 2-step RTPCR method (Wang et al. 1995). Different primer sets were shown to have different detection limits

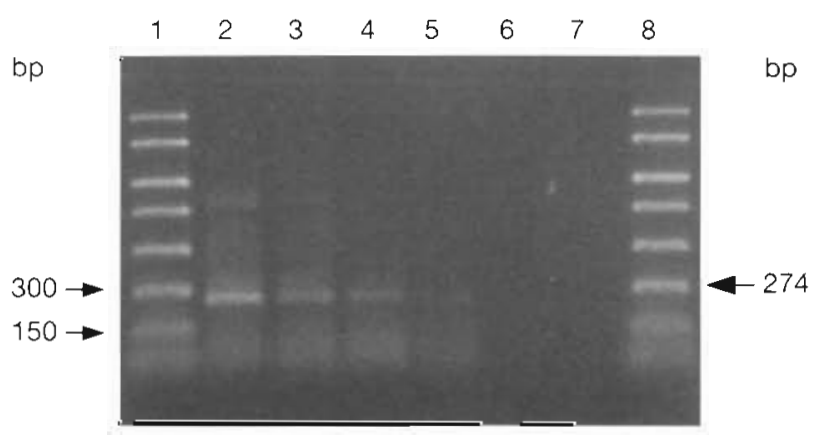

Fig. 3. Detection limit of the single tube RT-PCR using the primer $D$ set. Lanes 1 and 8: molecular weight standard; Lane 2: $1.5 \mathrm{pg}$; Lane 3: $150 \mathrm{fg}$; Lane 4: $15 \mathrm{fg}$; Lane 5: $1.5 \mathrm{fg}$; Lane 6:0.15 fg; Lane 7:0.015 fg 


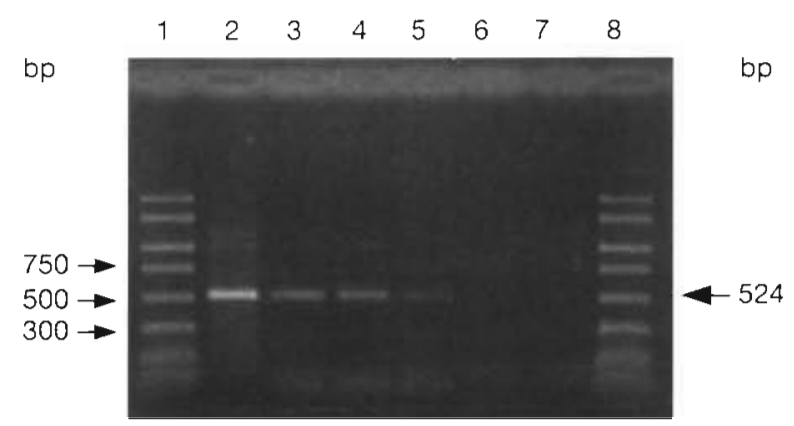

Fig. 4. Detection limit of the single tube RT-PCR using the primer $F$ set. Lanes 1 and 8 : molecular weight standard; Lane 2: $15 \mathrm{ng}$; Lane 3: $1.5 \mathrm{ng}$; Lane 4: $150 \mathrm{pg}$; Lane 5: $15 \mathrm{pg}$; Lane 6: $1.5 \mathrm{pg}_{\text {; Lane }} 7: 150 \mathrm{fg}$

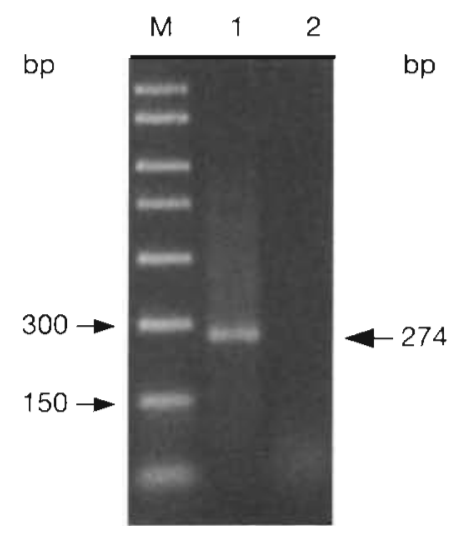

Fig. 5. IPNV RNA detection from fish organs by the single tube RT-PCR assay using the primer Pr D set. Lane M: molecular weight standard; Lane 1: IPNV (WB strain); Lane 2: uninfected fish organs

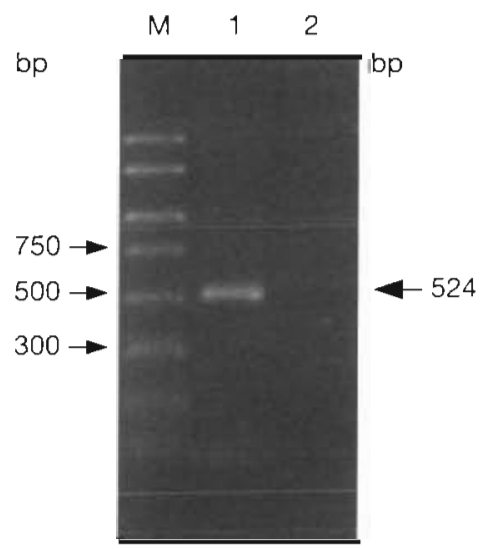

Fig. 6. IPNV RNA detection from fish organs by the single tube RT-PCR assay using the primer Pr F set. Lane M: molecular weight standard; Lane 1: IPNV (WB strain); Lane 2: uninfected fish organs in this single tube RT-PCR. This might be due to the position and length of the gene that was amplified. The Pr F primer amplified a distant region, 807 to $1330 \mathrm{bp}$, within the VP2 gene of the IPNV, while the Pr D primer amplified the 419 to $693 \mathrm{bp}$ region of the gene. The lower detection limit of $\operatorname{Pr} D$ may be due to the length of the amplified product: a shorter gene sequence is much more easily amplified. The relationship of concentrations between reverse transcriptase (RTase) and Taq polymerase activities has been described (Lee et al. 1994). Taq polymerase activity may be completely inhibited when the RTase concentration increases because an amplification product was not obtained. Lee et al. (1994) used different concentrations of RTase and Taq polymerase to reduce the interference between the 2 enzymes in a tube. We have tried unsuccessfully to use mineral oil to separate the RT and PCR reactions, but found that the mineral oil was too light in weight to fully divide the 2 reactions. Finally, we found that wax was firm enough to completely separate the 2 reactions until the reaction temperature reached $45^{\circ} \mathrm{C}$. The expected products were consistently amplified by the single-tube method after mineral oil was replaced with wax.

Theoretically, the amount of amplification product increases if the PCR cycles are extended. However, this increase is limited by several factors, one of which is the enzymatic stability of Taq polymerase following thermal cycle reactions. The half-life of Taq polymerase at 92.5 and $95^{\circ} \mathrm{C}$ is 130 and $40 \mathrm{~min}$, respectively. Hence, the amplification product can be increased by increasing the number of the PCR cycles but the temperature for denaturation of the DNA template may be the limiting factor (Lee et al. 1994).

Our results show that a sensitive and specific, singletube RT-PCR may be a feasible alternative tool for detecting IPNV.

Acknowledgements. We thank Dr H. Y. Chou, Dr B. L. Nicholson, Dr L. H. Lee, and Dr J. R. Winton for kindly donating their monoclonal antibodies and virus as gifts for this research. This work was supported by the Council of Agriculture, Taiwan, ROC [84-AST-1.1-FAD-62(39) and 85-AST-1.1-FAD$49(38)]$

\section{LITERATURE CITED}

Blake SL, Schill WB, McAllister PE, Lee MK, Singer JT, Nicholson BL (1995) Detection and identification of aquatic birnaviruses by PCR assay. J Clin Microbiol 33: $835-839$

Brown F (1986) The classification and nomenclature of viruses: summary of results of meetungs of the International Committee on Taxonomy of Viruses in Sendai, September 1984. Intervirology 25:141-143

Christie KE, Ness S, Djupvik HO (1990) Infectious pancreatic necrosis virus in Norway: partial serotyping by monoclonal antibodies. J Fish Dis 13:323-327 
Diaz-Ruiz JR, Kaper JM (1978) Isolation of viral doublestranded RNAs using a $\mathrm{LiCl}$ fractionation procedure. Prep Biochem 8:1-17

Dobos P (1976) Size and structure of the genome of infectious pancreatic necrosis virus. Nucleic Acids Res 3:1903-1924

Dobos P (1996) The molecular biology of infectious pancreatic necrosis virus (IPNV). Annu Rev Fish Dis 5:25-54

Dobos P, Hill BJ, Hallett R, Kells DTC, Becht $H$, Teninges D (1979) Biophysical and biochemical characterization of five animal viruses with bisegmented double-stranded RNA genomes. J Virol 32:593-605

Dopazo CP, Hetrick FM, Samal SK (1994) Use of cloned cDNA probes for diagnosis of infectious pancreatic necrosis virus infections. J Fish Dis 17:1-16

Duncan R, Dobos P (1986) The nucleotide sequence of infectious pancreatic necrosis virus (IPNV) dsRNA A segment reveals one large ORF encoding a precursor protein. Nucleic Acids Res 14:5934-5935

Duncan R, Mason CL, Nagy E, Leong J, Dobos P (1991) Sequence analysis of infectious pancreatic necrosis virus genome segment B and its encoded VP1 protein: aputative RNA-dependent RNA polymerase lacking the Gly-AspAsp motif. Virology 181:541-552

Elazhary MA, Lagace SY, Cousineau G, Roy RS, Berthiaume L, Paulhus P, Fretchette JL (1976) Outbreak of infectious pancreatic necrosis virus in yearling brook trout, Salvelinus fontinalis. J Fish Res Bd Can 33:2621-2625

Gelfand DH, White TJ (1990) Thermostable DNA polymerase. In: Innis $\mathrm{A}$, Gelfand $\mathrm{H}$, Sninsky JJ (eds) PCR protocols, a guide to methods and application. Academic Press, London, p 129-141

Havarstein L, Kalland SKH, Christie KE, Endresen C (1990) Sequence of the large double-stranded RNA segment of the N1 strain of infectious pancreatic necrosis virus: a comparison with other Birnaviridae. J Gen Virol 71:299-308

Hedrick RP, Fryer JL, Chen SN, Kou GH (1983) Characteristics of four birnaviruses isolated from fish in Taiwan. Fish Pathol 18:91-97

Hsu YL, Chiang SY, Lin ST, Wu JL (1989) The specific detection of infectious pancreatic necrosis virus in infected cells and fish by the immunodot blot method. J Fish Dis 12 : $561-571$

Kawasaki ES (1990) Amplification of RNA. In: Innis MA, Gelfand DH, Sninsky JJ (eds) PCR protocols, a guide to methods and application. Academic Press, London, p 21-27

Kimura T, Yoshimizu M, Yasuda H (1984) Rapid, simple serological diagnosis of infectious pancreatic necrosis by coagglutination test using antibody-sensitized Staphylococci. Fish Pathol 19:25-33

Lee LH, Ting LJ, Shien JH, Shieh HK (1994) Single-tube, noninterrupted reverse transcription-PCR for detection of infectious bursal disease virus. J Clin Microbiol 32: $1268-1272$

Responsible Subject Editor: J.-A. Leong, Corvallis, Oregon, USA
Lee MK, Blake S, Singer J, Nicholson BL (1995) Detection of EEV and other Asian aquatic birnaviruses by polymerase chain reaction (PCR) assay. In: Shariff $M$, Subasinghe RB, Arthur JR (eds) Proceedings of the Second Symposium on Disease in Asian Aquaculture. Fish Health Section, Asian Fisheries Society, Manila

Lopez-Lastra M, Gonzalez M, Jashes M, Sandino AM (1994) A detection method for infectious pancreatic necrosis virus (IPNV) based on reverse transcription (RT)- polymerase chan reaction (PCR). J Fish Dis 17:269-282

MacDonald RD, Dobos P (1981) ldentification of the protein encoded by each genome of infectious pancreatic necrosis virus. Virol 114:414-422

Manning DS, Leong JC (1990) Expression in Escherichia coli of the large genomic segment of infectious pancreatic necrosis virus. Virology 179:16-25

Mertens PPC, Jamieson PB, Bobos P (1982) In vitro RNA synthesis by infectious pancreatic necrosis virus-associate RNA polymerase. J Gen Virol 59:47-56

Nagy E, Duncan R, Krell P, Becht H (1987) Mapping of the large genome segment of infectious pancreatic necrosis virus by hybrid arrested translation. Virology 158:211-217

Novoa B, Barja JL, Figueras A (1995) Entry and sequential distribution of an aquatic birnavirus in turbot (Scophthalmus maximus). Aquaculture 131:1-9

Persson RH., MacDonald RD (1982) Evidence that infectious pancreatic necrosis virus has a genome linked protein. J Virol 44:437-443

Rlmstad E, Homes E, Olsvik O, Hyliseth B (1990) Identification of a double-stranded RNA virus by using polymerase chain reaction and magnetic separation of the synthesized DNA segments. J Clin Microbiol 28:2275-2278

Rodak L, Pospisil Z, Tomanek J, Vesely T, Obr T, Valicek L (1988) Enzyme-linked immunosorbent assay (ELISA) detection of infectious pancreatic necrosis virus (IPNV) in culture fluids and tissue homogenates of the rainbow trout, Salmo gairdneri Richardson. J Fish Dis 11. $225-235$

Shankar KM, Yamamoto T (1994) Prevalence and pathogenicity of infectious pancreatic necrosis virus (IPNV) associated with feral lake trout, Salvelinus namaycush (Walbaum). J Fish Dis 17:461-470

Sneller LN, Coelen RT, Mackenzie JS (1992) Reverse transcriptase inhibits Taq polymerase activity. Nucleic Acids Res 20:1487-1490

Wang WS, Lee JS, Blake SL, Nicholson BL (1995) Developing the polymerase chain reaction technique to detect aquatic birnavirus. Taiwan J Vet Med Anim Husb 65:167-180

Wolf K (1988) Infectious pancreatic necrosis virus. In: Wolf $\mathrm{K}$ (eds) Fish viruses and fish viral disease. Cornell University Press, Ithaca, NY, p 115-157

Xu L, Harbour D. McCrae MA (1990) The application of polymerase chain reaction to the detection of rataviruses in faeces. J Virol Meth 27:29-38

Manuscript first received: September 27, 1996

Revised version accepted: December 5, 1996 